\title{
Genetic structure of European populations of Salmo salar L. (Atlantic salmon) inferred from mitochondrial DNA
}

\author{
E. E. NIELSEN* $\uparrow$, M. M. HANSEN $\$$ \& V. LOESCHCKE $\dagger$ \\ $\dagger$ Department of Ecology and Genetics, University of Aarhus, Ny Munkegade, 8000 Aarhus and $\ddagger$ Danish Institute for \\ Fisheries Research, Department of Inland Fisheries, Vejlsøvej 39, 8600 Silkeborg, Denmark
}

\begin{abstract}
The genetic relationships between the only natural population of Atlantic salmon (Salmo salar L.) in Denmark and seven other European salmon populations were studied using RFLP analysis of PCR amplified mitochondrial DNA segments. Six different haplotypes were detected by restriction enzyme analyses of the NADH dehydrogenase 1 segment, employing four endonucleases. Significant genetic differentiation was observed among populations. A hierarchical analysis of the distribution of the mtDNA variability revealed that only a small part was distributed among geographical groups within the study area. No correlation was found between genetic and geographic distance among populations. The effective migration of females $(\mathrm{Nm})_{\mathrm{F}}$ among rivers was estimated to be approximately one per generation.
\end{abstract}

Keywords: effective migration rate, gene flow, genetic differentiation, mitochondrial DNA RFLP, Salmo salar.

\section{Introduction}

Throughout its range, Atlantic salmon (Salmo salar L.) exhibits large interpopulational genetic differences (Ryman, 1983; Ståhl, 1987; Blanco et al., 1992; Jordan et al., 1992). These differences have been attributed to restricted gene flow among populations caused by efficient homing. Restricted gene flow is likely to increase the role of genetic drift within populations and may also facilitate local adaptations.

In recent years, interest in the genetic structure of Atlantic salmon populations has increased because of growing exploitation of stocks, destruction of suitable habitat and intentional or unintentional humanmediated gene flow. Intentional gene flow is the result of the supplementation of natural populations of salmon with salmon of non-native origin (Thompson \& Russell, 1991; Vasquez et al., 1993), and unintentional gene flow is caused by domesticated salmon that escape from fish farms. The reproductive success of non-native salmonids in nature, however, has generally been shown to be less than that of native salmonids (Thompson \& Russell, 1991; Flemming \& Gross 1993; Vasquez et al., 1993; Hansen et al., 1995).

The introduction of non-native salmon has poten-

*Correspondence.

(c) 1996 The Genetical Society of Great Britain. tial implications for wild salmon populations. It can lead to displacement of the native populations, to homogenization of the genetic material by swamping and, possibly, to outbreeding depression (Hindar et al., 1991). Evidence of outbreeding depression is, however, scarce in salmonid fishes, but even a low degree of spawning intrusion by cultured fish (or stocked fish of foreign origin) may have a serious impact on native populations (Hutchings, 1991).

Genetic markers for distinguishing between source populations are essential for studying the implications of 'mixing' salmon of different geographical origin. Mitochondrial DNA (mtDNA) provides a useful marker system. MtDNA has a lower effective population size than nuclear genes, approximately equal to half of the effective number of females (Birky et al., 1983), and is therefore more subject to drift than nuclear genes. This may cause salmon populations to exhibit larger differentiation for mtDNA than revealed by traditional allozyme electrophoresis.

So far, the application of RFLP (Restriction Fragment Length Polymorphism) analysis of the whole mtDNA has been used to distinguish between salmon from Scotland and Norway (Knox \& Verspoor, 1991). However, until now the number of individuals screened and the number of salmon populations studied have been limited owing to the 
time consuming procedures associated with these methods. The development of PCR and specific mtDNA primers has solved many of these problems. Crude preparations of total genomic DNA can be used for routinely amplifying mtDNA segments. We have applied a PCR-based method using the primers described by Cronin et al. (1993) to study the genetic structure of salmon populations on different geographical levels, with particular reference to the only extant Danish salmon population.

\section{Materials and methods}

\section{Salmon populations}

The only remnant wild population of Atlantic salmon in Denmark is found in the Skjern River (SKJ). The river runs into the North Sea on the west coast of Jutland (Fig. 1). The Skjern River population has been severely reduced as a result of human activities during this century. It has been isolated for several decades because of the extinction of all other Danish salmon populations. At present, the rivers

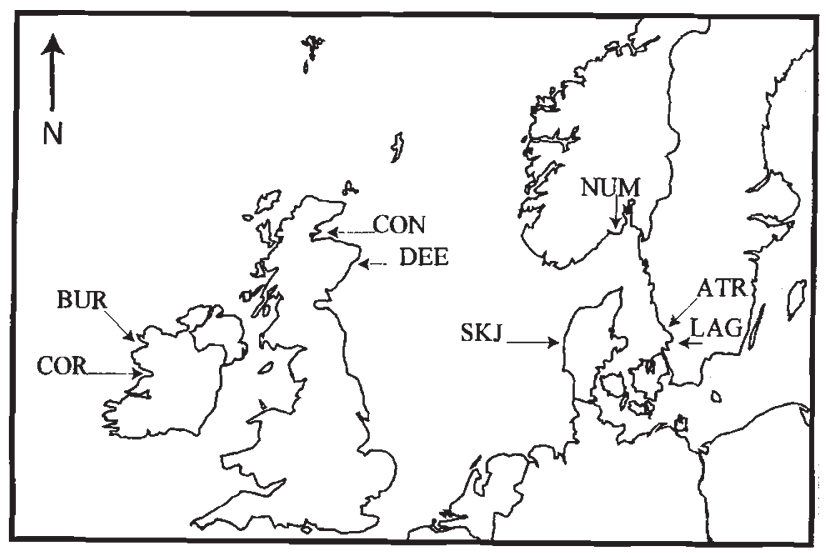

Fig. 1 Approximate location of the river systems sampled. See Table 1 for list of abbreviations. containing natural populations of Atlantic salmon closest to the Skjern River are situated on the Swedish west coast. Sea ranching of salmon in Denmark has never occurred, so gene flow from domesticated salmon could only have occurred via escapees from aquaculture in other countries. The other populations used in this study were sampled from various river systems in Europe, centred mainly around the North Sea: the rivers Ätran and Lagan of the Swedish west coast, which have been intensively stocked with native salmon, Numedalslågen from Southern Norway, Conon and Dee (two tributaries, Girnock and Baddoch Burns) from Eastern Scotland, and two Irish populations, Burrishoole and Corrib from the Atlantic coast.

Sample sites of fish are summarized in Table 1. Young salmon (parr) from the Skjern River were collected in 1989 by electrofishing and stored at $-20^{\circ} \mathrm{C}$. Fish from Atran, Lagan, Conon, Burrishoole and Corrib were provided by the Brusgaard Production School, Denmark. To reduce the possibility that small sample size could result in the imported samples showing less genetic variation than their source populations, fertilized eggs were collected from at least 20 breeding pairs in the native rivers. The fish from Brusgaard were sampled as parr and as young salmon ready for migration to sea (smolt). Fish from Numedalslågen, Norway, were sampled as parr, and muscle samples were stored in ethanol. Samples from the Girnock and Baddoch Burns were provided as extracted total genomic DNA from adult salmon.

\section{Mitochondrial DNA analyses}

DNA was extracted as described by Taggart et al. (1992). We amplified two segments of the mitochondrial genome: ND 1 (NADH dehydrogenase 1) and the control region (D-loop) with the primers described by Cronin et al. (1993). Two other sets of

Table 1 Populations of Atlantic salmon sampled, sample size $(N)$, list of abbreviations, year of sampling and life stage of fish sampled

\begin{tabular}{lrlrl}
\hline Sample & $N$ & Abbreviations & Year & Life stage \\
\hline Skjern River (Denmark) & 33 & SKJ & 1989 & Parr \\
Ätran (Sweden) & 27 & ATR & 1994 & Smolt \\
Lagan (Sweden) & 37 & LAG & 1994 & Parr \\
Numedalslågen (Norway) & 26 & NUM & 1993 & Parr \\
Conon (Scotland) & 34 & CON & 1994 & Parr \\
Dee (Scotland) & 111 & DEE & 1993 & Adult \\
Burrishoole (Ireland) & 32 & BUR & 1994 & Parr \\
Corrib (Ireland) & 27 & COR & 1994 & Parr \\
\hline
\end{tabular}


primers, ND3/4 and ND 5/6 (NADH dehydrogenase 3 and 4, and NADH dehydrogenase 5 and 6, respectively), were also tried, but could not be readily amplified for routine analysis.

PCR reactions were set up in a $50 \mu \mathrm{L}$ volume composed of $0.2 \mu \mathrm{M}$ of each primer, $10 \mathrm{~mm}$ Tris- $\mathrm{HCl}$ (pH 9.0), $1.5 \mathrm{~mm} \mathrm{MgCl}_{2}, 50 \mathrm{~mm} \mathrm{KCl,} 0.01$ per cent $(\mathrm{w}: \mathrm{v})$ gelatine, 0.1 per cent Triton $\mathrm{X}-100$ and 0.5 units of Taq or Tbr polymerase. As a template, approximately $200 \mathrm{ng}$ of total genomic DNA was added in $1 \times$ TE buffer.

The following amplification cycles gave the best results for the ND 1 segment: denaturation at $95^{\circ} \mathrm{C}$ for $1 \mathrm{~min}$, eight cycles consisting of annealing at $50^{\circ} \mathrm{C}$ for $30 \mathrm{~s}$, extension at $70^{\circ} \mathrm{C}$ for $2.5 \mathrm{~min}$, denaturation at $95^{\circ} \mathrm{C}$ for $45 \mathrm{~s}$, followed by 21 cycles at $53^{\circ} \mathrm{C}$ for $30 \mathrm{~s}, 70^{\circ} \mathrm{C}$ for $2.5 \mathrm{~min}, 95^{\circ} \mathrm{C}$ for $45 \mathrm{~s}$ and a final annealing at $53^{\circ} \mathrm{C}$ for $30 \mathrm{~s}$, with a final extension for $4 \mathrm{~min}$ at $70^{\circ} \mathrm{C}$. For the D-loop segment, an annealing temperature of $55^{\circ} \mathrm{C}$ yielded the largest amounts of DNA.

The amplified segments of DNA were screened for restriction site polymorphism by using the following endonucleases: $A l u \mathrm{I}, A v a \mathrm{I}, A v a \mathrm{II}, B a m \mathrm{HI}$, DdeI, DraI, HaeIII, HhaI, HincII, HinfI, HpaII, $M b o \mathrm{I}, M w o \mathrm{I}, R s a \mathrm{I}, S s p \mathrm{I}$ and TaqI. From the findings of an initial screening of 50 fish pooled from all populations, we chose only to amplify the ND 1 segment and used only AvaII, HaeIII, HinfI and RsaI in our analyses of PCR products.

Amplified segments were digested with each of the four chosen restriction enzymes, using $8 \mu \mathrm{L}$ of the PCR reaction for each digestion. The amount of restriction endonuclease used for each digestion varied between 0.5 and 2.5 units. The digested samples were electrophoresed on 2 per cent agarose gels in $0.5 \times \mathrm{TBE}$ buffer (Tris-borate-EDTA) followed by staining with ethidium bromide. Visualization of the fragments was carried out under UV light and recorded on Polaroid film. Each restriction morph was designated with a capital letter. Composite genotypes (haplotypes) were designated by four letters, one for each restriction enzyme used in this study.

\section{Data analysis}

The size of the restriction fragments was estimated by comparison to a hundred base pair ladder (Pharmacia). Fragments larger than approximately $100 \mathrm{bp}$ were recorded. For estimation of fragment lengths we used a least squares method (Schaffer, 1983). The genetic relationship among haplotypes was analysed by calculating the mean number of substi- tutions per site between all pairs of haplotypes based on the restriction fragment data, as described by Nei \& Li (1979). Construction of a tree describing the genetic relationships among haplotypes was carried out according to the algorithm of Fitch \& Margoliash (1967) using the programs $D$ from the REAP package (McElroy et al., 1991) and FITCH from the PHYLIP package (Felsenstein, 1993). Pairwise tests for homogeneity of haplotype frequencies between samples were performed using a Monte Carlo simulation approach (Roff \& Bentzen, 1989), with the program MONTE from the REAP package (McElroy $e t$ al., 1991). Levels of significance were adjusted according to the sequential Bonferroni method as described by Rice (1989).

The AMOVA (analyses of molecular variance) method and program developed by Excoffier et al. (1992) was used for analysing the distribution of genetic variation among populations. This method quantifies levels of genetic variation by analysis of variance. The program allows for partitioning the variance components into different hierarchical levels: variance among groups, variance among populations within groups and variance within populations. The AMOVA program was also used for calculation of $\Phi$-statistics: $\Phi_{\mathrm{ST}}$, the correlation of random haplotypes within subpopulations, relative to that of random haplotypes drawn from the total population; $\Phi_{\mathrm{CT}}$, the correlation of random haplotypes from a group of subpopulations, relative to that of random pairs of haplotypes drawn from the whole population; $\Phi_{\mathrm{SC}}$, the correlation of random haplotypes within subpopulations, relative to that of random pairs drawn from within that geographical group. For the estimation of $\Phi_{\mathrm{ST}}$ all populations were included, whereas for the organisation of the populations into group levels, geographical groups that only contained one population were excluded (Skjern River and Numedalslågen). The other populations were organized into three groups according to their respective geographical region: (i) Ätran and Lagan; (ii) Conon and Dee; and (iii) Corrib and Burrishoole. The relationship between geographical and genetic distance was investigated by comparing distances measured over sea from river to river, with genetic distances computed as $\Phi_{\text {ST }}$ (Slatkin, 1993) between sample pairs. The relationship was tested by use of the program G-Mantel from the G-Stat 3 package (Siegismund, 1993). Gene flow was estimated as the effective number of migrating mitochondria per generation, which is expected to be approximately the number of migrating females per generation (Hudson et al., 1992). 


\section{Results}

The size of the amplified ND 1 fragment was $2 \mathrm{~kb}$. Digestion patterns revealed restriction site differences for four of the endonucleases. AvaI, HinfI and $R s a \mathrm{I}$ detected two morphs, whereas three morphs were revealed by using HaeIII (Table 2). Differences between morphs could in all cases be explained by the gain or loss of one restriction site.

Six composite genotypes (haplotypes) were identified (Table 3). The genetic relationship among haplotypes is summarized in Fig 2. The distribution of haplotypes between localities (Table 3 ) shows that haplotype 2 was the most common and appeared in all populations studied. Haplotypes 1, 3 and 4 were found in most populations. Only one 'private' haplotype was found (haplotype 5 from the Dee). Signi- ficant differences in haplotype frequencies were found for the majority of the pairwise comparisons between populations (Table 4); however, only the populations from Skjern River and Lagan were significantly different from all other populations. Most of the genetic variance was distributed within populations (Table 5). The 'among population within group' level contributed 20 per cent to the total variance. A very small proportion of the genetic variation was distributed among groups. The $\Phi_{\text {ST }}$ value of 0.335 for all populations, when substituted in the equation: $(\mathrm{Nm})_{\mathrm{F}}=\frac{1}{2}\left(1 / \Phi_{\mathrm{ST}}-1\right)$ (Hudson et al., 1992), provided an estimate of gene flow among populations of $(\mathrm{Nm})_{\mathrm{F}}=0.99$. The Skjern River population showed the largest average genetic distances to other populations, with pairwise $\Phi_{\mathrm{ST}}$ values ranging from 0.26 to 0.54 . The relationship

Table 2 Approximate size in base pairs (bp) of restriction fragments, for Atlantic salmon ND 1 digested with four endonucleases: Ava II, HaeIII, HinfI and $R s a \mathbf{I}$

\begin{tabular}{|c|c|c|c|c|c|c|c|c|c|}
\hline \multirow{2}{*}{$\begin{array}{l}\text { Restriction } \\
\text { endonuclease } \\
\text { Restriction } \\
\text { morph }\end{array}$} & \multicolumn{2}{|c|}{$A v a \mathrm{II}$} & \multicolumn{3}{|c|}{ HaeIII } & \multicolumn{2}{|c|}{$\operatorname{Hin} \mathrm{fI}$} & \multicolumn{2}{|c|}{ Rsa I } \\
\hline & A & B & A & B & $\mathrm{C}$ & A & B & A & B \\
\hline \multirow[t]{10}{*}{$\begin{array}{l}\text { Fragment } \\
\text { sizes (bp) }\end{array}$} & & 940 & 630 & 630 & & 1040 & 1040 & & 480 \\
\hline & 540 & & 570 & & 570 & 570 & & 390 & 390 \\
\hline & 410 & 410 & & 500 & & & 530 & 310 & \\
\hline & 340 & & & & 380 & 400 & 400 & 300 & 300 \\
\hline & 320 & 320 & & & 230 & & & 270 & 270 \\
\hline & 220 & 220 & 210 & 210 & 210 & & & 230 & 230 \\
\hline & 160 & 160 & 180 & 180 & 180 & & & 210 & 210 \\
\hline & & & 170 & 170 & 170 & & & 160 & \\
\hline & & & 150 & 150 & 150 & & & & \\
\hline & & & 110 & 110 & 110 & & & & \\
\hline
\end{tabular}

Only fragments larger than one hundred base pairs are included.

Table 3 Haplotype frequencies for Atlantic salmon and sample sizes $(N)$

\begin{tabular}{lccccccc}
\hline $\begin{array}{l}\text { Haplotype } \\
\text { Number }\end{array}$ & $N$ & $\begin{array}{c}\text { AAAA } \\
1\end{array}$ & $\begin{array}{c}\text { BBBB } \\
2\end{array}$ & $\begin{array}{c}\text { AABA } \\
3\end{array}$ & $\begin{array}{c}\text { BBBA } \\
4\end{array}$ & $\begin{array}{c}\text { ACAA } \\
5\end{array}$ & $\begin{array}{c}\text { AAAB } \\
6\end{array}$ \\
\hline Skjern River & 33 & 0.67 & 0.30 & 0 & 0.03 & 0 & 0 \\
Ätran & 27 & 0.11 & 0.74 & 0.11 & 0 & 0 & 0.04 \\
Lagan & 37 & 0 & 0.22 & 0.68 & 0.10 & 0 & 0 \\
Numedalslågen & 26 & 0 & 0.65 & 0.23 & 0.12 & 0 & 0 \\
Conon & 34 & 0.24 & 0.24 & 0.09 & 0.44 & 0 & 0 \\
Dee & 111 & 0.09 & 0.54 & 0.07 & 0.25 & 0.05 & 0 \\
Burrishoole & 32 & 0.22 & 0.44 & 0 & 0.28 & 0 & 0.06 \\
Corrib & 27 & 0 & 0.41 & 0.15 & 0.44 & 0 & 0 \\
\hline
\end{tabular}

Haplotypes are denoted by capital letters in the following order: AvaII, HaeIII, HinfI, Rs I and by number, 1-6. 
between genetic and geographical distance (Fig. 3) was not significant (Mantel test: $P=0.8$ ).

\section{Discussion}

\section{Variability in Atlantic salmon mtDNA}

Clonal diversity of mtDNA in Atlantic salmon was low. One reason for this low level is that we only analysed one segment of the mtDNA. However, the detected low number of clones is in accordance with other results on populations of Atlantic salmon by King et al. (1993), Hovey et al. (1989) and Pallson \& Arnason (1994) and is also in accordance with low

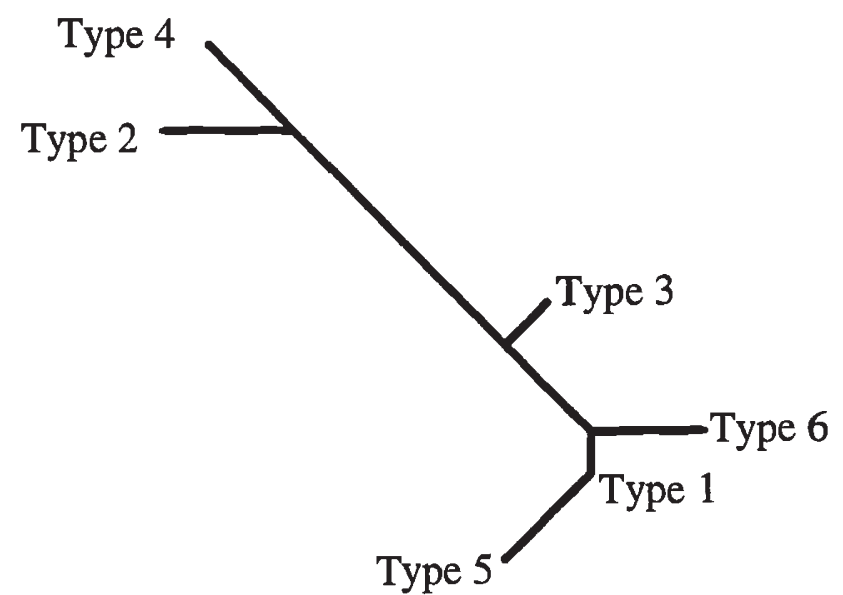

Fig. 2 Phylogenetic tree summarizing the genetic relationship among Atlantic salmon haplotypes. The tree was based on the mean number of base substitutions per site between haplotypes (Nei \& Li, 1979) and constructed according to the algorithm by Fitch \& Margoliash (1967), using the program FITCH from the PHYLIP program package (Felsenstein, 1993). levels of genetic variation in this species as detected by other methods of genetic analyses (Davidson et al., 1989). Low genetic variation is often found for fish species inhabiting formerly glaciated regions (Billington \& Hebert, 1991).

\section{Phylogeny and geographical distribution of haplotypes}

We found no obvious correspondence between phylogeny and geographical distribution. The four most common haplotypes were widely distributed (Table 3) among river systems and were represented in all geographical regions. The single 'private' haplotype discovered was from the Dee. Results from digestion of the whole mtDNA by other authors (Hovey et al., 1989; Palva et al., 1989; King et al., 1993) have not revealed more than two digestion morphs employing the restriction endonuclese HaeIII. In our analyses we have identified three morphs using this restriction endonuclease, the rarest of these morphs being the one that separates haplotype 6 from haplotype 1 .

Table 5 Genetic variance components and $\Phi$-statistics for Atlantic salmon populations estimated using the AMOVA program (Excoffier, 1992)

\begin{tabular}{lrrrr}
\hline Genetic variance & & \multicolumn{2}{c}{$\Phi$ statistics } \\
\hline Among groups & $0.2 \%$ & $\Phi_{\mathrm{Cr}}$ & 0.002 \\
Among populations within groups & $20.3 \%$ & $\Phi_{\mathrm{SC}}$ & 0.203 \\
Within populations & $79.5 \%$ & $\Phi_{\mathrm{ST}}$ & $0.335 \dagger$ \\
\hline
\end{tabular}

$\dagger$ For calculation of this value, all populations were included.

Table 4 Pairwise tests for homogeneity of haplotype frequencies between populations of Atlantic salmon

\begin{tabular}{lcccccrr}
\hline & \multicolumn{1}{c}{ SKJ } & ATR & LAG & NUM & CON & DEE & BUR \\
\hline ATR & $22.4^{* * *}$ & & & & & & \\
LAG & $49.0^{* * *}$ & $29.6^{* * *}$ & & & & & \\
NUM & $22.0^{* *}$ & $8.2 \mathrm{NS}$ & $13.5^{* *}$ & & & & \\
CON & $30.4^{* * *}$ & $22.9^{* * *}$ & $31.6^{* * *}$ & $19.5^{* *}$ & & & \\
DEE & $51.1^{* * *}$ & $14.2 \mathrm{NS}$ & $59.4^{* * *}$ & $10.9 \mathrm{NS}$ & $14.4^{*}$ & & \\
BUR & $16.8^{* *}$ & $14.7^{*}$ & $37.4^{* * *}$ & $17.9^{* *}$ & $8.2 \mathrm{NS}$ & $14.7 \mathrm{NS}$ & \\
COR & $35.1^{* * *}$ & $18.8^{* *}$ & $18.6^{* * *}$ & $7.1 \mathrm{NS}$ & $8.3 \mathrm{NS}$ & $8.6 \mathrm{NS}$ & $13.5^{*}$ \\
\hline
\end{tabular}

The significances of the $\chi^{2}$ were estimated using a Monte Carlo approach (Roff \& Bentzen, 1989).

Values of significance were adjusted according to the sequental Bonferroni method. $\chi^{2}$ values of the original matrix are tabulated. *** $P<0.001,{ }^{* *} P<0.01,{ }^{*} P<0.05$; NS: nonsignificant. 


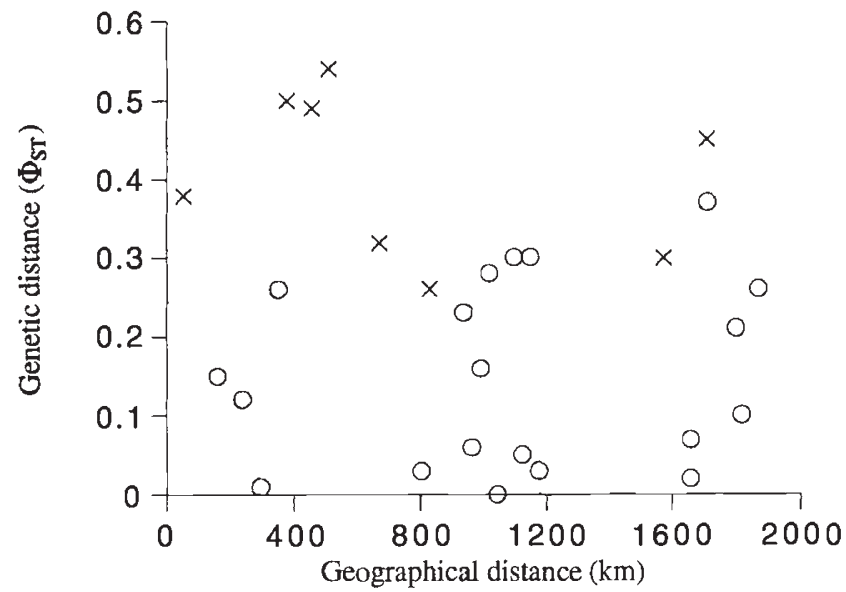

Fig. 3 Relationship between genetic (pairwise $\Phi_{\mathrm{ST}}$ values) and geographical distance $(\mathrm{km})$ between Atlantic salmon populations. Relationships involving the Skjern River are indicated with $\mathrm{X}$.

This lack of correlation between phylogeny and geographical distance probably arises from the postglacial colonization of the studied geographical regions by Atlantic salmon. The number of mutations accumulated in mtDNA during this rather short period has not been sufficient for populations to diverge. The findings from a related species with a similar evolutionary history, the brown trout (Salmo trutta L.), shows a similar pattern (Hansen \& Loeschcke, 1996). Therefore genetic differences observed between haplotypes, for the major part, probably represent 'old' variation predating the last glaciation (about ten thousand years), as is observed for allozyme variation (Ståhl, 1987).

\section{Genetic differentiation and gene flow among populations}

The results from the analyses of molecular variance (Table 5) suggest considerable genetic differentiation among populations from different river systems. The large differences are partly explained from the specific gene flow dynamics of mtDNA. Population genetics theory for nuclear genes predicts genetic differentiation among populations if the exchange of effective migrants per generation is less than one (Wright 1931). However, the effective population size for mtDNA is only about one-quarter that of the effective population size for nuclear genes (Birky et al., 1983), which means that strong genetic differentiation may occur if the effective migration is less than four individuals per generation. The calculated number of migrating females $(\mathrm{Nm})_{\mathrm{F}}$ of 0.99 corresponds to a total number of approximately two effective migrants per generation for a nuclear gene, assuming equal contribution to gene flow from the two sexes. The estimated gene flow is well within the range of estimated values from studies using allozyme variation, $\mathrm{Nm}=1.42$ (Elo, 1993, from $57 \mathrm{popu}$ lations), 2.5 (Ståhl, 1981, Baltic populations) and 2.3 (Koljonen, 1989, four Finnish stocks), which indicates that estimates of gene flow based on data obtained from allozyme electrophoresis and RFLP analysis of mtDNA are comparable. This is also supported by the results of Hansen \& Loeschcke (1996) who obtained similar results for both methods in a study of genetic differentiation of brown trout populations. The similarity of results obtained with haploid and diploid genetic markers is, however, not evidence of equal migration rates of males and females. Higher migration rates among males and a female-biased sex ratio could create the same pattern.

Most of the genetic variance for nuclear genes is distributed within populations of Atlantic salmon (Ryman, 1983; Ståhl, 1987; Jordan et al., 1992). A marked difference exists between the major geographical groups of Atlantic salmon (North American, European and Baltic), contributing about 30 per cent to the genetic variance (Ståhl, 1987). The hierarchical analysis of variance presented here (Table 5) shows that a similar large component of the mtDNA variance is found within populations. The very low 'among group' variance component is likely to be the result of the narrow geographical range covered in this study. MtDNA differences have been proposed to exist between major groups (North American and European, Bermingham et al., 1991). It would be interesting to apply this method on a larger geographical scale to investigate possible additional large groupings. We observed that part of the variance was distributed among populations within groups, a finding which may be attributed to the limited populations within each group. A sampling design that includes more populations within a narrow geographical range could clarify this.

\section{Relationship between genetic and geographical distance}

The lack of correlation between genetic and geographical distance implies that the gene flow among populations of Atlantic salmon on the geographical scale studied here follows an island model. This is supported by the findings of Elo (1993), who found no correspondence for geographical distances smaller than $2000 \mathrm{~km}$. However, he found a good 
correlation for geographical distances larger than $2000 \mathrm{~km}$. It would be interesting to apply studies of mtDNA on a larger geographical level to see if this 'isolation-by-distance effect' can also be found for mtDNA.

\section{The Skjern River salmon population}

The Skjern River population is an illustrative example of the importance of gene flow and genetic drift for the genetic population structure of Atlantic salmon. The low population size of this specific population has probably lead to the high degree of genetic differentiation (Table 4). The only other population that is significantly different from all other populations studied is the population of the River Lagan, which has experienced a severe bottleneck in this century (G. Holdensgaard, personal communication). Many populations of Atlantic salmon are now being stocked with hatchery-reared fish of native or non-native origin including the two populations mentioned here (SKJ, LAG). Both stocking strategies may disturb the natural population structure of Atlantic salmon. Stocking fish of native origin can lead to a lowered effective population size, if the number of wild founders used for supportive breeding is limited (Ryman, 1991). If fish of non-native origin were stocked this may lead to increased levels of gene flow (Evans, 1991; Crozier, 1993). Careful evaluation of stocking practices is therefore needed if any impact on population structure is to be avoided.

\section{MtDNA as a genetic marker for Atlantic salmon population studies}

Mitochondrial DNA can be considered as one hypervariable locus, representing only a small part of the total genome and with gene flow dynamics different from nuclear genes. This has led to doubt about the representativeness of results obtained by employing mtDNA as a genetic marker for studies of population structure (Ferguson et al., 1991; see also Pamilo \& Nei, 1988; Degnan, 1993). However, we found striking similarities with results on population structure of Atlantic salmon as revealed by other types of analyses. From our point of view, mtDNA analysis therefore appears to be a fast and reliable method of obtaining population data with high resolution.

\section{Acknowledgements}

We are grateful to Bob Krebs and Philip W. Hedrick for helpful comments on the manuscript and to all those who provided us with salmon samples: Søren Larsen and Jørgen Jørgensen helped us to obtain samples from the Skjern river. Gert Holdensgaard, John Taggart, Kjetil Hindar, Snæbjørn Pallson and Einar Arnasson kindly provided us with Atlantic salmon samples. We would like to thank the Danish Inland Fisheries Laboratory and the Danish National Research Council (grant no. 94-0163-1) for financial support.

\section{References}

BERMINGHAM, E., FORBES, S. H., FRIEDLAND, K. AND PLA, C. 1991. Discrimination between Atlantic salmon (Salmo salar) of North American and European origin using restriction analysis of mitochondrial DNA. Can. J. Fish. Aquat. Sci., 48, 884-893.

BIRKY, C. W., Jr., MARUYAMA, T. AND FUERST, P. 1983. An approach to population and evolutionary genetic theory for genes in mitochondra and chloroplasts, and some results. Genetics, 103, 513-527.

BILLINGTON, N. AND HEBERT, P. D. N. 1991. Mitochondrial DNA diversity in fishes and its implications for introductions. Can. J. Fish. Aquat. Sci., 48 (Suppl. 1), 80-93.

BLANCO, G., SÁNCHEZ, J. A., VÁSQUEZ, E., RUBIO, J. AND UTTER, F. M. 1992. Genetic differentiation among natural European populations of Atlantic salmon, Salmo salar L., from drainages of the Atlantic Ocean. Anim. Genet., 23, 11-18.

CRONIN, M. A., SPEARMAN, W. J., WilMot, R. L., PATTON, J. C. AND BICKHAM, J. w. 1993. Mitochondrial DNA variation in Chinook (Oncorhynchus tshawytcha) and chum salmon $(O$. keta) detected by restriction enzyme analysis of polymerase chain reaction (PCR) products. Can. J. Fish. Aquat. Sci., 50, 708-715.

CROZIER, w. w. 1993. Evidence of genetic interaction between escaped farmed salmon and wild Atlantic salmon (Salmo salar L.) in a Northern Irish River. Aquaculture, 113, 19-29.

DAVIDSON, W. S., BIRT, T. P. AND GREEN, J. M. 1989. A review of genetic variation in Atlantic salmon, Salmo salar L., and its importance for stock identification, enhancement programmes and aquaculture. J. Fish Biol., 34, 547-560.

DEGNAN, S. M. 1993. The perils of single gene trees mitochondrial vs. single copy nuclear DNA variation in white-eyes (Aves: Zosteropidae). Mol. Ecol., 2, 219-225.

ELO, K. 1993. Gene flow and conservation of genetic variation in anadromous Atlantic salmon (Salmo salar). Hereditas, 119, 149-159.

EVANS, D. O. AND CAMPBELL C. W. 1991. Loss of exploited, indigenous populations of lake trout, Salvelinus namaycush, by stocking of non-native stocks. Can. J. Fish. Aquat. Sci., 48 (Suppl. 1), 134-147.

EXCOFfIER, L., SMOUSE, P. E. AND QUATTRo, J. M. 1992. Analyses of molecular variance inferred from metric distances among DNA haplotypes: application to 
human mitochondrial DNA restriction data. Genetics, 131, 479-491.

FELSENSTEIN, J. 1993. PHYLIP (Phylogeny Inference Package, Version 3.5c). Department of Genetics, SK, University of Washington, Seattle, WA.

FERGUSON, M. M., DANZMANN, R. G. AND HUTCHINGS, J. A. 1991. Incongruent estimates of population differentiation among brook charr, Salvelinus fontinalis, from Cape Race, Newfoundland, Canada, based upon allozyme and mitochondrial DNA variation. J. Fish Biol., 39 (Suppl. A), 79-85.

FitCH, W. M. AND MARGOliash, E. 1967. Construction of phylogenetic trees. Science, 155, 279--284.

FLEMMING, I. A. AND GROSS, M. R. 1993. Breeding sucess of hatchery and wild coho salmon(Oncorhynchus kisutch) in competition. Ecol. Appl., 3, 230-345.

HANSEN, M. M. AND LOESCHCKE, v. 1996. Genetic differentiation among Danish brown trout (Salmo trutta) populations, as detected by RFLP analysis of PCR amplified mitochondrial DNA segments. J. Fish Biol., 48, 422-436.

HANSEN, M. M., HYNES, R. A., LOESCHCKE, V. AND RASMUSSEN, G. 1995. Assessment of the stocked or wild origin of anadromous brown trout (Salmo trutta L.) in a Danish river system, using mitochondrial DNA RFLP analysis. Mol. Ecol., 4, 189-198.

HINDAR, K., RYMAN, N. AND UTTER, F. 1991. Genetic effects of cultured fish on natural fish populations. Can. J. Fish. Aquat. Sci., 48, 945-957.

HOVEY, S. J., KING, D. P. F., THOMPSON, D. AND SCOTT, A. 1989. Mitochondrial DNA and allozyme analysis of Atlantic salmon, Salmo salar., in England and Wales. $J$. Fish Biol., 35 (Suppl. A), 253-260.

HUTCHings, J. A. 1991. The threat of extinction to native populations experiencing spawning intrusions by cultured Atlantic salmon. Aquaculture, 98, 119-132.

HUDSON, R. R. SLATKIN, M. AND MADDISON, W. P. 1992. Estimation of gene flow from DNA sequence data. Genetics, 132, 583-589.

JORDAN, W. C., YOUNGSON, A. F., HAY, D. W. AND FERGUSON. A. 1992. Genetic protein variation in natural populations of Atlantic salmon (Salmo salar) in Scotland: temporal and spatial variation. Can. J. Fish. Aquat. Sci., 49, 1863-1872.

KING, D. P. F., HOVEY, S. J., THOMPSON, D. AND SCOTT, A. 1993. Mitochondrial DNA variation in Atlantic salmon, Salmo salar L., populations. J. Fish Biol., 42, 25-33.

KNOX, D. AND VERSPOOR, E. 1991. A mitochondrial DNA restriction fragment length polymorphism of potential use for discrimination of farmed Norwegian and wild Atlantic salmon populations in Scotland. Aquaculture, 98, 249-257.

KOLJONEN, M.-L. 1989. Electrophoretically detectable genetic variation in natural and hatchery stocks of Atlantic salmon in Finland. Hereditas, 110, 23-35

MCELROY, D., MORAN, P., BERMINGHAM, E. AND KORNFIELD, I. 1991. REAP. The Restriction Enzyme Analyses Package. Version 4.0. Department of Zoology, Migratory Fish
Research Institute and Center for Marine Studies, University of Maine, Orono, USA.

NEI, M. AND LI, W. H. 1979. Mathematical models for studying genetic variation in terms of restriction endonucleases. Proc. Natl. Acad. Sci. U.S.A., 76, 5269-5273.

PALLSON, S. AND ARNASON, E. 1994. Sequence variation for cytochrome $b$ genes of three salmonid species from Iceland. Aquaculture, 128, 29-39.

PALVA, T. K., LEHVÄSLAiHO, H. AND PALVA E. T. 1989. Identification of anadromous and non-anadromous salmon stocks in Finland by mitochondrial DNA analysis. Aquaculture, 81, 237-244.

PAMILO, P. AND NEI, M. 1988. Relationship between gene trees and species trees. Mol. Biol. Evol., 5, 568-583.

RICE, W. R. 1989. Analyzing tables of statistical tests. Evolution, 43, 223-225.

ROFF, D. A. AND BENTZEN, P. 1989. The statistical analyses of mitochondrial DNA polymorphisms: $\chi^{2}$ and the problem of small samples. Mol. Biol. Evol., 6, 539-545.

RYMAN, N. 1983. Patterns of distribution of biochemical genetic variation in salmonids: differences between species. Aquaculture, 33, 1-21.

RYMAN, N. 1991. Conservation genetics considerations in fishery management. J. Fish Biol., 39 (Suppl. A), 211-224.

SCHAFFER, H. E. 1983. Determination of DNA fragment size from gel electrophoresis mobility. In: Weir, B. S. (ed.) Statistical Analyses of DNA Sequence Data, pp. 1-14. Dekker, New York.

SIEGISMUND, H. R. 1993. G-Stat, ver. 3. Genetical Statistical Programs for the Analysis of Population Data. The Arboretum, Royal Veterinary and Agricultural University, Kierkegaardsvej 3A, DK2970 Hoersholm, Denmark.

SLATKIN, M. 1993. Isolation by distance in equilibrium and non-equilibrium populations. Evolution, 47, 264-279.

STÅHL, G. 1981. Genetic differentiation among natural populations of Atlantic salmon (Salmo salar) in Northern Sweden. In: Ryman, N. (ed.) Fish Gene Pools. Ecol. Bull., 34, 95-105.

STÅHL, G. 1987. Genetic population structure of Atlantic salmon. In: Ryman, N. and Utter, F. (eds) Population Genetics and Fishery Management, pp. 121-140. University of Washington Press, Seattle.

TAGGART, J. B., HYNES, R. A., PRODÖHL, P. A. AND FERGUSON, A. 1993. A simplified protocol for routine total DNA isolation from salmonid fishes. J. Fish Biol., 40, 963-965.

THOMPSON, D. AND RUSSELL, 1. C. 1991. Allele frequency variation at the ${ }_{s} A A T-4$ locus as a potential measure of the relative performance of native and introduced Atlantic salmon in the river Test. Aquaculture, 98, 243-247.

VASQUEZ, E., PRESA, P., SÁNCHEZ, J. A., BLANCO, G. AND UTTER, F. 1993. Genetic characterization of introduced populations of Atlantic salmon, Salmo salar, in Asturias (Northern Spain). Hereditas, 119, 47-51.

WRIGHT, s. 1931. Evolution in Mendelian populations. Genetics, 16, 97-159. 